\title{
Continued stable isotope studies on the Greenland ice-sheet margin at Pâkitsoq, north-east of Jakobshavn, central West Greenland
}

\author{
Niels Reeh, Anne Letréguilly and Hans Oerter
}

In close cooperation with the GGU glacier-hydrological field team a small group from the Alfred Wegener Institute for Polar and Marine Research (AWI), Bremerhaven, West Germany, worked for four weeks in July-August 1988 on the West Greenland ice-sheet margin at Paakitsup Akuliarusersua, about $40 \mathrm{~km}$ northeast of Ilulissat/Jakobshavn. Previous stable isotope studies in the area by GGU (Reeh \& Thomsen, 1986) have documented that ice deposited in the inland regions of the ice sheet during the last ice age is now exposed as a roughly $600 \mathrm{~m}$ wide band at the surface of the ice sheet near the ice edge (Reeh et al., 1987a). The main purpose of the AWI expedition was to perform detailed (continuous) surface sampling for stable isotope analysis $\left(\delta^{18} \mathrm{O}\right)$ through the transition from the last glacial period (Wisconsinan) to the present post-glacial period (Holocene). A comparison of such a detailed isotopic record from the surface of the ice margin with similar records from deep Greenland ice cores should tell how well the continuity of the layer sequence is preserved in the ice-margin record. This question is of crucial importance for evaluating the potential yield of the ice margin as a source of easily accessible old ice.

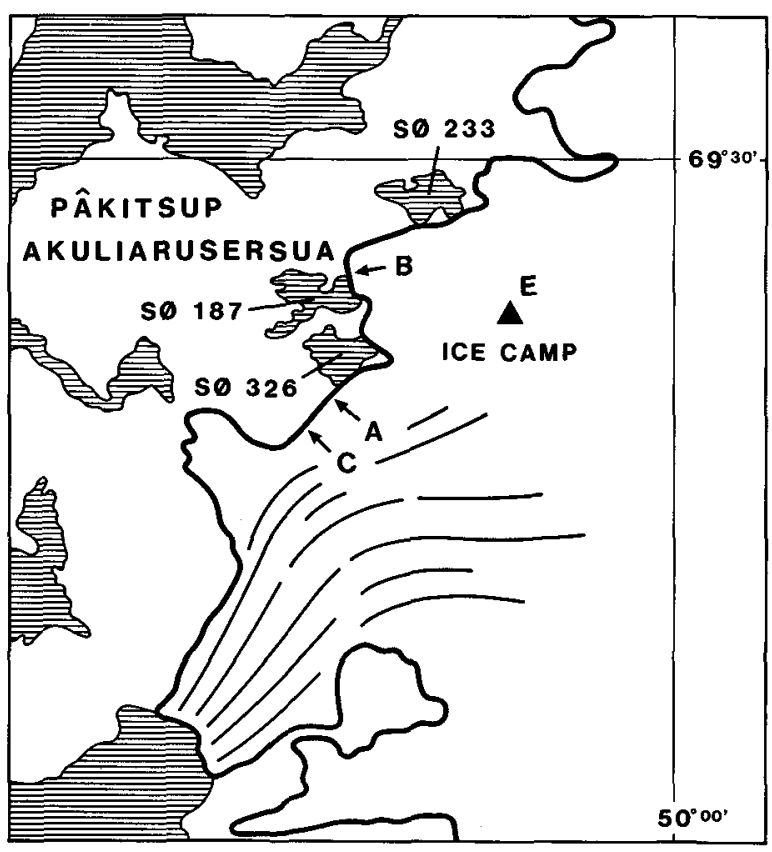

Fig. 1. Locations of sites where samples were taken in 1988.
Besides the detailed sampling programme, other surface investigations were performed:

(1) Collection of surface ice and water samples for stable isotope analysis at other sites on the ice margin.

(2) Collection of precipitation for stable isotope analysis.

(3) Collection of water samples from lakes in the ice-free foreland for stable isotope analysis.

(4) Placement of stakes in the ice for ablation and movement studies.

(5) Surveying work for location of sampling sites and for movement measurements.

(6) Measurement of the conductivity of surface waters along profile lines on the ice-sheet margin.

\section{Sampling programme}

Altogether, about 2000 ice and water samples for stable isotope analysis were collected from six different ice-margin locations and from eight different lakes, ranging in elevation between 187 and $394 \mathrm{~m}$.

Profile A. About 1450 samples were collected in a 750 $\mathrm{m}$ long Profile A transverse to the ice margin (fig. 1), and more than half of these were taken continuously as $20 \mathrm{~cm}$ samples along a $170 \mathrm{~m}$ section through the transition from Wisconsinan to Holocene ice. The location of the transition was known from a previously sampled profile (Reeh et al., 1987a) running approximately parallel to Profile $A$ and $50 \mathrm{~m}$ to the north of it. Detailed notes were made about surface elevations and ice-surface structures (e.g. blue bands) along the profile line which was also photographed section by section enabling the $\delta$ record to be correlated with the surface features. Profile A will therefore provide an excellent possibility for studying the continuity of the layer sequences exposed at the surface of the ice margin and also for studying the reproducibility of the ice-margin isotopic records.

Profile $B$. The presence of Wisconsinan ice at the outermost $450 \mathrm{~m}$ of the glacier tongue terminating in $S \varnothing$ 187 (fig. 1) has been documented previously by GGU (Thomsen, 1987). For the purpose of ice-dynamic modelling (Reeh et al., 1987b) it is important to locate the transition from Wisconsinan to Holocene ice at the glacier surface, which was not done unambiguously by the GGU pilot study. For this reason, and also in order to 
investigate the reproducibility of the $\delta$ records on a distance range of a few kilometres, 175 samples at $2 \mathrm{~m}$ intervals were collected on the glacier tongue in a $350 \mathrm{~m}$ section through the Wisconsinan/Holocene transition.

Profile $C$. As previously described (Reeh \& Thomsen, 1986) the outermost $200 \mathrm{~m}$ of the ice margin at the Profile A location consists of clear ice (appearing blackish when looked into) that is almost completely covered by a surface-moraine layer of varying thickness. At location $\mathrm{C}$ the 'black' ice is exposed in a steep cliff several metres high. Here it can be seen that the black ice has a layered structure with many dirt bands and dirt inclusions. This supports the interpretation that the black ice is regelation ice formed by refreezing of meltwater at the base of the ice sheet at some distance behind the ice edge. At two locations, about $50 \mathrm{~m}$ apart, two near-vertical 7.2 and $4 \mathrm{~m}$ high profiles were sampled at intervals ranging between 5 and $40 \mathrm{~cm}$. Altogether $c .100$ samples were taken for analysis for $\delta\left({ }^{18} \mathrm{O}\right)$ as well as for $\delta(D)$. A plot of $\delta(D)$ versus $\delta\left({ }^{18} \mathrm{O}\right)$ will show if the black ice has been through one or more melting/refreezing cycles (Souchez \& Jouzel, 1984).

Profile E. Near Ice Camp (fig. 1) a $20 \mathrm{~m}$ surface profile parallel to the ice movement was sampled continuously in $20 \mathrm{~cm}$ samples over a $20 \mathrm{~m}$ section. At this location flow-model calculations indicate that the ice is $3000-4000$ years old and the width (measured along the surface) of the annual layers, re-surfacing at this location, is estimated to be in the order of $3 \mathrm{~m}$. The purpose of the sampling was to see if the original annual $\delta$ cycle is still preserved in the re-surfacing ice and, if so, to measure the layer width to compare with the value predicted by the ice-dynamic modelling.

Other $\delta$ sampling locations. About $50 \mathrm{~m}$ to the north of Profile $\mathrm{A}$, at a distance of $c .30 \mathrm{~m}$ from the transition from moraine covered ice to ice without moraine cover, two $2 \mathrm{~m}$ sections were sampled continuously in 10 to 20 $\mathrm{cm}$ samples across what seemed to be an active shear band. The band extended for $c .50 \mathrm{~m}$ parallel to the ice margin, and was characterized by a step change in surface elevation of up to $10 \mathrm{~cm}$, with the lower elevation to the side towards the margin. At this side numerous mollusc shells and shell fragments were found at the ice surface together with mud, sand and small pebbles. Apparently the material originated from the shear band and was distributed at the surface over a distance of a few metres downstream of the shear band by meltwater flows. A collection of shells were sampled and given to Anker Weidick, GGU, for species determination and ${ }^{14} \mathrm{C}$ dating.

A few ice samples for $\delta\left({ }^{18} \mathrm{O}\right)$ analysis were also taken at two locations south of Paakitsup Akuliarusersua, i.e. at the southern margin of Jakobshavn Isbræ and at the southern margin of Alangardliup sermia in the Christianshåb district. This sampling is a contribution to a general survey of the isotopic composition of the ice exposed along the margins of the Greenland ice-sheet.

Analysis of the samples. The analysis of the samples for $\delta\left({ }^{18} \mathrm{O}\right)$ is presently in progress at AWI. Water samples taken in vertical profiles from the pro-glacial lakes, Sø 187 and $S \varnothing 233$, show that the lakes are vertically homogeneous with respect to $\delta\left({ }^{18} \mathrm{O}\right)$. The precipitation samples, on the other hand, show large variations from -17 to $-25.5 \% \delta\left({ }^{18} \mathrm{O}\right)$. Preliminary results from the continuously sampled section of Profile A are promising. Even though ice from the blue bands seems to have $\delta$ values that are $7-8 \%$ higher than those of the surrounding white ice, there seems to be no discontinuity in the white-ice $\delta$ values across the blue bands. The explanation of the $\delta$ anomaly of the blue-band ice is not yet known. However, it is hoped that further stable isotope studies (e.g. combined $\delta\left({ }^{18} \mathrm{O}\right)$ and $\delta(\mathrm{D})$ analysis) can throw light on the formation of the blue bands. The analysis of all $\delta\left({ }^{18} \mathrm{O}\right)$ samples is expected to be completed in the early summer of 1989 . The combined analysis for $\delta\left({ }^{18} \mathrm{O}\right)$ and $\delta(D)$ will be performed at the Institut für Radiohydrometrie der Gesellschaft für Stralen- und Umwelt-Forschung, München-Neuherberg, West Germany, and is expected to be completed at the end of 1988.

\section{Surveying programme}

A surveying station on the mountain slope facing the ice margin at the location of Profile A was established and connected to the existing network of surveying points established by the Greenland Technical Organization. From this station several points in Profile A were positioned, two of which (established as stakes drilled into $6 \mathrm{~m}$ depth $c .500$ and $1000 \mathrm{~m}$ from the ice margin) can also be used to locate the profile in the future and for measurements of mass balance and velocity.

A similar surveying programme was carried out at the glacier terminating in $\$ \varnothing 187$ in order to locate Profile $\mathrm{B}$, and to position stakes previously drilled in by GGU (Thomsen, 1987) for mass balance and velocity measurements.

\section{Conductivity measurements}

The conductivity of the surface waters was measured with a WTW Conduktometer (LF 191) along two $650 \mathrm{~m}$ profile lines running parallel to the estimated ice-flow direction near Ice Camp (fig. 1). The profiles were about $200 \mathrm{~m}$ apart. About 1500 readings were taken in 
each profile by dipping the electrode into numerous water-filled cryoconite holes in a search for high conductivity signals of volcanic origin. The method was suggested by Claus Hammer, Geophysical Institute, University of Copenhagen. High conductivity signals were found at similar positions in the two profiles, but it is not yet clear whether these can be interpreted as reflecting a volcanic eruption.

Acknowledgements. Anker Weidick (GGU) collected ice samples at the margins of Jakobshavn Isbræ and Alangardliup sermia, Claus Kern-Hansen and Jens Valeur (Greenland Technical Organization) collected water samples from $S \varnothing 187$ and Sø 233, Mark Meier and Tad Pfeffer (INSTAAR, University of Colorado) helped collect ice samples, Hans Oerlemans (University of Utrecht) and Henrik Højmark Thomsen (GGU) helped with the conductivity measurements, and Henrik $\mathrm{H} ø$ mark Thomsen, Roger J. Braithwaite, Ole B. Olesen, and Carl Bøggild (GGU) helped with the logistic organization.

\section{References}

Reeh, N. \& Thomsen, H. H. 1986: Stable isotope studies on the Greenland ice-sheet margin. Rapp. Grønlands geol. Unders. 130, 108-114.

Reeh, N., Thomsen, H. H. \& Clausen, H. B. 1987a: The Greenland ice-sheet margin - a mine of ice for paleo-environmental studies. Palaeogeogr., Palaeoclimat., Palaeoecol. 58, 229-234.

Reeh, N., Hammer, C. U., Thomsen, H. H. \& Fisher, D. A. 1987b: Use of trace constituents to test flow models for ice sheets and ice caps. Publ. Assoc. int. hydrol. Scient. 170, 299-310.

Souchez, R. \& Jouzel, J. 1984: On the isotopic composition in $\delta \mathrm{D}$ and $\delta^{18} \mathrm{O}$ of water during freezing. J. Glaciol. 30(106), 369-372.

Thomsen, H. H. 1987: Continued glaciological work north-east of Jakobshavn, West Greenland. Rapp. Grønlands geol. Unders. 135, 84-87.

N. R., A. L., H. O. Alfred Wegener Institute for Polar and Marine Research, Postfach 120161, Columbusstrasse D-2850 Bremerhaven West Germany.

\title{
Glacier-climate studies 1987-1988 at Qamanârssûp sermia, West Greenland
}

\author{
Roger J. Braithwaite
}

As part of the GGU programme of hydropower investigations in West Greenland, glaciological and climatological measurements were made at the Qamanârssûp sermia field station for the seven summers 19801986. However, the station was deactivated at the end of the 1986 field season (Braithwaite, 1987) and only a reduced measurement programme was carried out in 1987-1988.

\section{Field work 1987-1988}

The automatic climate station at base camp was kept in operation and the glaciological programme was limited to what could be done on one-day visits by helicopter in May and in late August. In 1987 both visits had to be curtailed due to unforeseen problems with helicopters. This meant that not all stakes could be found in 1987 and that there was not enough time to redrill other stakes which therefore melted out. The glaciological programme in 1988 was reduced to maintaining the '751' stakes, near to the old base camp, and stake 15 high up on the ice sheet (fig. 1).

\section{Results 1987-1988}

The data for net ablation are given in Table 1 for seven stakes in 1986/87 and two stakes in 1987/88 compared with the 1979-1986 means at the same stakes. There was very high ablation in 1987 so that the ' 751 ' stakes melted out while the net ablation at the remaining seven stakes was higher than the 7-year mean by 0.2 to $1.3 \mathrm{~m}$ water. By contrast, net ablation in $1987 / 88$ at the two stakes are respectively 0.3 and $0.2 \mathrm{~m}$ water lower than the average.

Data for monthly mean temperatures from the automatic climate station are given in Table 2; data for August 1988 are still incomplete.

The high ablation in the summer of 1987 was obviously due to exceptionally high temperatures in both June and August 1987 although July 1987 was rather cool. Overall, the 1987 summer was the warmest on record although the net ablation was generally a little less than in 1985 which was the next warmest summer. However, ablation in 1985 was higher than could be expected from the high temperatures because the degree-day factor was also higher than normal (Braith- 